\title{
Effect of extended lactations on cow milk and reproductive performance
}

\author{
ANNA SAWA and MARIUSZ BOGUCKI
}

Department of Cattle Breeding, Faculty of Animal Breeding and Biology, University of Technology and Life Sciences, Bydgoszcz, Poland

\section{Abstract}

Frequency of extended lactations and their effect on milk and reproductive performance of cows from the active population of 11891 Black and White cows with different proportions of Holstein Fresian inheritance were analysed. It was found that lactations longer than a 305-day standard lactation were quite common in the analysed population of Black-and-White cows improved with the Holstein-Friesian breed. The age of cows, the level of yield in a standard lactation and season of the year had a significant effect on the proportion of extended lactations. Lactation extension had a beneficial effect on milk yield in full lactation but was detrimental to fertility. The efficiency of lactation extension was found to increase with the increasing level of yield in the standard lactation.

Keywords: cow, extended lactations, milk performance, reproductive performance

\section{Zusammenfassung}

\section{Der Einfluss verlängerter Laktationsdauer auf Milch- und Fruchtbarkeitsleistungen bei Kühen}

Untersucht wurde der Einfluss einer verlängerten Laktationsdauer auf den Milchertrag und die Fruchtbarkeitsleistung an 11891 Schwarzbuntrindern mit unterschiedlichem Holstein Friesian Genanteil. In den untersuchten Populationen konnte eine durchschnittlich 305-tägige Laktationsdauer ermittelt werden. Das Alter der Kühe, das Durchschnittsniveau einer Standardlaktation und die Kalbezeit hatten einen signifikanten Einfluss auf die Auswirkungen der Laktationsverlängerung. Die Verlängerung erbrachte einen höheren Milchertrag in der Gesamtlaktation aber eine Verminderung bei den Fruchtbarkeitsleistungen.

Schlüsselwörter: Kuh, Verlängerung Laktationsdauer, Milchleistung, Fruchtbarkeitsleistung

\section{Introduction}

Intensive breeding over the last 40 years coupled with improvement of environmental conditions resulted in the doubling of the cows' milk yield in many countries. Higher milk production increased changes in cow productivity, including extended lactations and reduced fertility (BIELFELDT et al. 2004, GULIŃSKI et al. 2004, KRZYŻEWSKI and REKLEWSKI 2003, SAWA et al. 2002, HINRICHS et al. 2006, SALAMOŃCZYK and GULIŃSKI 2007, SEELAND 
and HENZE 2003, SÖLKNER et al. 2000). According to GULIŃSKI et al. (2004), prolongation of the lactation period by $30,60,120,180$ and over 180 days increased fat corrected milk production by $3.3 \%, 9.6 \%, 21.4 \%, 33.8 \%$ and $55.5 \%$, respectively. For cows yielding over $9000 \mathrm{~kg}$ of milk, KRZYŻEWSKI et al. (2004) showed a beneficial effect of extended lactations not only on milk yield and composition but also on basic reproductive parameters.

The cow's lactation period lasts from calving to drying off. The average length of this period is approximate 10 months (with a standard lactation of 305 days), but in practice the fluctuations are considerable. Lactations shorter than standard ones occur in undernourished, sick or early fertilized cows. Extended lactations most often involve the extension of calving interval and are found in high-yielding cows (BORKOWSKA 2005). The possibility of extending lactations is increasingly considered as individual yields increase. According to SZAREK (1998), the idea of 18-month lactations was conceived at the same time in the USA and Europe. BERTILSSON et al. (1998) and KNIGHT et al. (1998) suggest that cows with extended lactations may generate larger profits as a result of increased lifetime milk yield, extended length of productive life, and lower cost of herd replacement.

The aim of the present study was to analyse the effect of lactation extension on the yield and fertility of cows and to determine factors affecting extended lactations.

\section{Material and methods}

Data used in the study originated from the SYMLEK database and concerned the milk and reproductive performance of 11891 Black-and-White cows improved with the HolsteinFriesian breed. The cows belonged to the active population of the Kujawsko-Pomorskie province, first calved in 2001 and were used or culled by 2007. The length of 57883 full lactations was calculated. After preliminary analysis of the data, statistical calculations were limited to 22432 lactations extending beyond 305 days. Extended lactation length, milk yield in a 305-day lactation and extension period, daily milk yield during the extension period, the proportion of milk obtained during the extension period in relation to 305-day lactation yield, as well as the length of consecutive calving intervals $(\mathrm{Cl})$, reproductive rest period (RRP) and number of inseminations after each calving $(1,2,3,>3)$ were calculated.

Statistical analysis was performed by means of two-way analysis of variance using the following linear model (SAS 2004):

$$
Y=\mu+a_{i}+b_{j}+(a b)_{i j}+e_{i j k}
$$

where $\mu$ is the overall mean, $a_{i}$ the effect of $i$-th extension of lactation ( $\leq 30,31-60,61-90$, 91-120, 121-150, 151-180, $>180$ days), $b_{j}$ the effect of $j$-th age of cows (lactation 1, 2, 3 $>3$ ) or $j$-th level of yield in a 305-day lactation $(\leq 5000 \mathrm{~kg}, 5001-7000,>7000)$ or $j$-th season of calving (III-V, VI-VIII, IX-XI, XII-II), $(a b)_{i j}$ the interaction between lactation extension $\times$ age of cow (or level of yield in a 305-day lactation or season of calving) and $\mathrm{e}_{i j k}$ the random error of observation.

Significant differences were checked using the Scheffe test. 
The $X^{2}$ independence test (SAS 2004) was used to analyse the frequency of extended lactations according to age of cow, level of yield in a 305-day lactation and season of calving. In addition, the CORR PEARSON procedure (SAS 2004) was used to calculate correlation coefficients between lactation extension length and individual performance traits of the cows.

\section{Results}

Full lactation yield (7 $204 \mathrm{~kg}$ milk) is considered high (Table 1). Lactation extension length averaged 84 days. During this period, an average of $1064 \mathrm{~kg}$ milk was obtained per cow, which accounted for approx. $17 \%$ of the yield in a 305 -day lactation. Fertility parameters are evidence of reproductive abnormalities.

Table 1

Performance traits of cows in the population studied

Leistungsmerkmale der Kühe in den utersuchten Populationen

\begin{tabular}{lc}
\hline Item & Value of trait \\
\hline Length of lactation extension, days & 84 \\
kg milk in 305-day lactation & 6140 \\
kg milk during lactation extension & 1064 \\
kg milk in full lactation & 7204 \\
kg milk/day during lactation extension & 12.8 \\
Proportion of milk during lactation extension as related to 305-day lactation, $\%$ & 17.3 \\
Calving interval, days & 439 \\
Reproductive rest period, days & 96 \\
Number of inseminations & 2.25 \\
\hline
\end{tabular}

Table 2

Frequency of extended lactations

Frequenzen der Laktationsverlängerung

\begin{tabular}{lcccccccc}
\hline Item & Number & \multicolumn{7}{c}{ Percentage of lactation extended by days } \\
& of lactations & $\leq 30$ & $31-60$ & $61-90$ & $91-120$ & $121-150$ & $151-180$ & $>180$ \\
\hline In general & 22432 & 29.12 & 21.36 & 15.21 & 10.67 & 7.42 & 5.10 & 11.12 \\
Age (lactation) & $X^{2}=284^{* *}$ & & & & & & & \\
1 & 8477 & 26.64 & 19.58 & 14.99 & 11.43 & 7.84 & 5.60 & 13.91 \\
2 & 6200 & 28.66 & 21.82 & 15.34 & 10.60 & 7.44 & 5.37 & 10.77 \\
3 & 4414 & 29.66 & 22.27 & 15.61 & 9.86 & 7.45 & 4.53 & 10.63 \\
$>3$ & 3440 & 35.57 & 23.83 & 14.97 & 9.94 & 6.26 & 4.07 & 5.36 \\
Level of yield per 305-day lactation & $X^{2}=166^{* *}$ & & & & & & \\
$\leq 5$ 000 & 6290 & 33.94 & 21.67 & 14.21 & 9.73 & 6.34 & 4.52 & 9.59 \\
5 001-7 000 & 10059 & 28.77 & 21.26 & 15.44 & 11.02 & 7.40 & 5.17 & 10.94 \\
$>7$ 000 & 6083 & 24.72 & 21.21 & 15.85 & 11.05 & 8.56 & 5.59 & 13.02 \\
Calving season $X^{2}=29^{*}$ & & & & & & & & \\
III-V & 5933 & 30.46 & 20.75 & 14.31 & 10.37 & 7.43 & 5.09 & 11.06 \\
VI-VIII & 5213 & 28.45 & 21.29 & 15.85 & 10.59 & 7.98 & 5.68 & 10.17 \\
IX-XI & 5269 & 28.54 & 22.17 & 15.39 & 10.99 & 6.98 & 4.86 & 11.06 \\
XII-II & 6017 & 28.90 & 21.32 & 15.37 & 10.75 & 7.30 & 4.82 & 11.53 \\
\hline
\end{tabular}

${ }^{*} P \leq 0.05, \quad{ }^{* * P} P \leq 0.01$ 
Out of 57883 full lactations, 22432 lactations (39\%) were longer than 305 days. It was shown that $29 \%$ lactations were extended by up to 30 days, $21 \%$ by $31-60$ days, $15 \%$ by $61-90$ days, $11 \%$ by $61-120$ days, $7 \%$ by $121-150$ days, $5 \%$ by $151-180$ days and $11 \%$ by over 180 days (Table 2).

The results of the $X^{2}$ test show significant $(P \leq 0.01)$ differences in the frequency of extended lactations according to all factors analysed in the experiment. The proportion of extended lactations was most differentiated by the age of cows (lactation number). As the number of calvings increased, the proportion of lactations extended up to 60 days increased and the proportion of lactations extended by over 90 days (especially by over 180 days) decreased 2.6-fold. As the level of yield per standard lactation increased, the proportion of lactations extended up to 30 days decreased (from 34 to $25 \%$ ) and the proportion of lactations extended beyond 60 days increased (from 9.6 to $13 \%$ ), with the greatest differences observed for extensions beyond 180 days. These tendencies seem desirable considering the increased efficiency of using high-yielding cows as their lactations became more extended. Most cows calved in winter and spring. The proportion of extended lactations within particular calving seasons remained constant.

The results concerning the effect of cow age and lactation extension on milk and reproductive performance are shown in Table 3. Regardless of cow's age, the extension of lactation beyond standard was paralleled by higher yield during 305-day lactation, with differences ranging from $458 \mathrm{~kg}$ milk for first calvers to $962 \mathrm{~kg}$ milk for third calvers. As lactations became longer, milk yield during the extension period increased (especially in third calvers) to $3609 \mathrm{~kg}$ in lactations extended beyond 180 days. As lactation increased, the proportion of milk obtained during the extension period increased in relation to the yield obtained per 305-day lactation. The proportion of milk obtained from first calvers during lactation extended by over 180 days accounted for as much as $62 \%$ of their yield during a 305-day lactation. The proportion of milk yield during the longest extension periods in relation to 305 -day yield was approx. $50 \%$ in second- and third-lactation cows and approx. $44 \%$ in older cows. Extending the lactation by 31-60 days caused a decrease in daily milk yield during the extension period in relation to daily yield of the cows, which prolonged their lactations to 30 days (the highest in the second lactation - by $3.4 \mathrm{~kg}$, the lowest in the third and next lactations - by $1.1 \mathrm{~kg}$ ). Further extension of lactations did not have a negative effect on daily milk yield during the extension period. There was a tendency towards increased daily milk yield as the lactation period became longer. This tendency was most pronounced during the third lactation, when milk yield increased by $2 \mathrm{~kg}$ As lactations extended, fertility was found to deteriorate, especially in first calvers. The significant relationship found in the experiment between the length of lactation extension and the length of calving interval (Cl) is considered obvious $\left(r=0.917^{* *}\right.$ ) (Table 6). $\mathrm{Cl}$ extension was caused not so much by longer RRP as by unsuccessful inseminations in consecutive cycles (number of inseminations was approx. 4 for lactations extended by over 180 days) (Table 3).

Milk yield during the extension period increased with the increasing level of yield in a 305-day lactation and with lactation extension (Table 4). As a result, milk yield during the extension period ranged from $136 \mathrm{~kg}$ for extension shorter than 30 days and standard lactation level of $\leq 5000 \mathrm{~kg}$ to as much as $4337 \mathrm{~kg}$ for extension longer than 180 days 


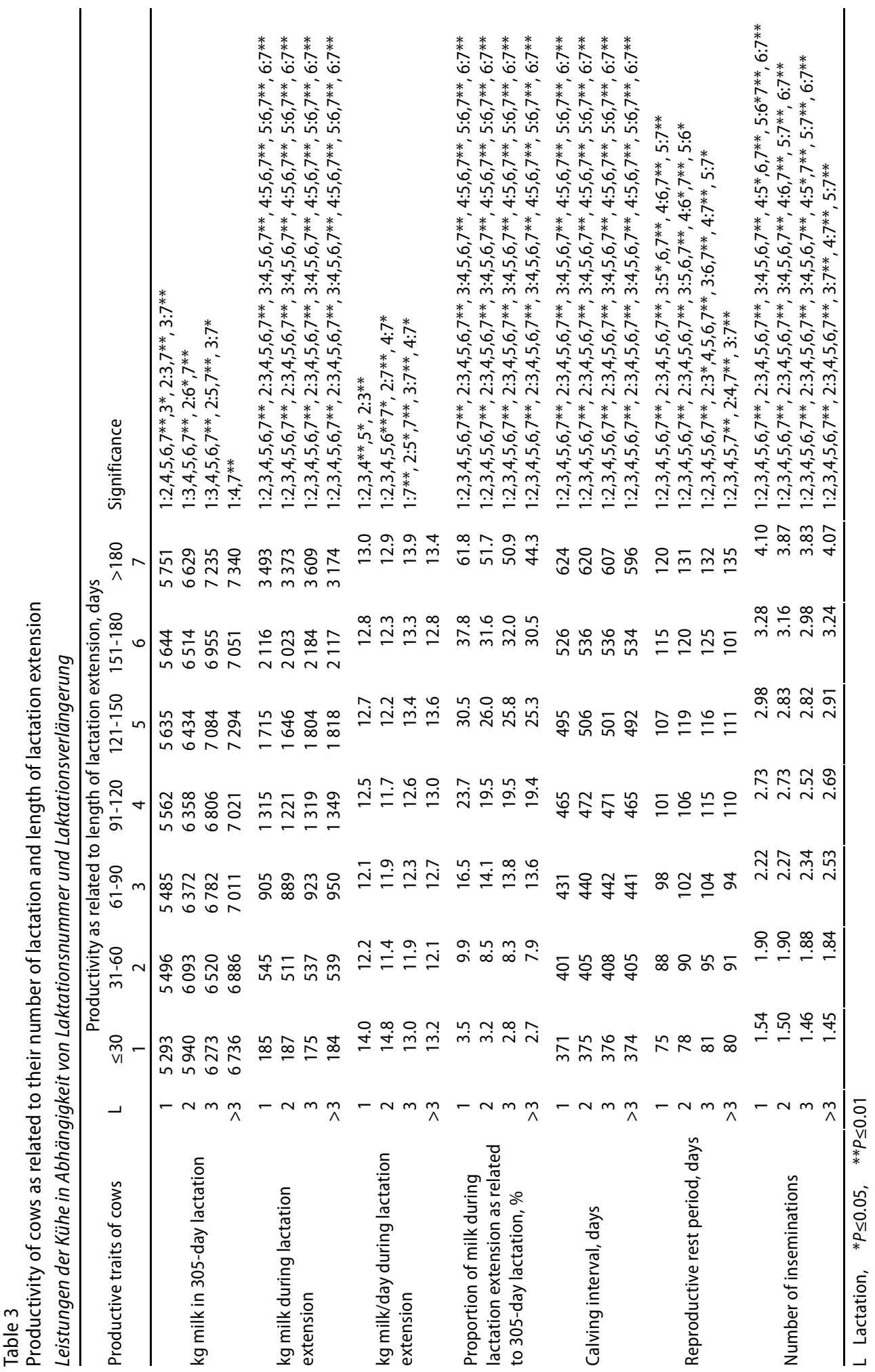




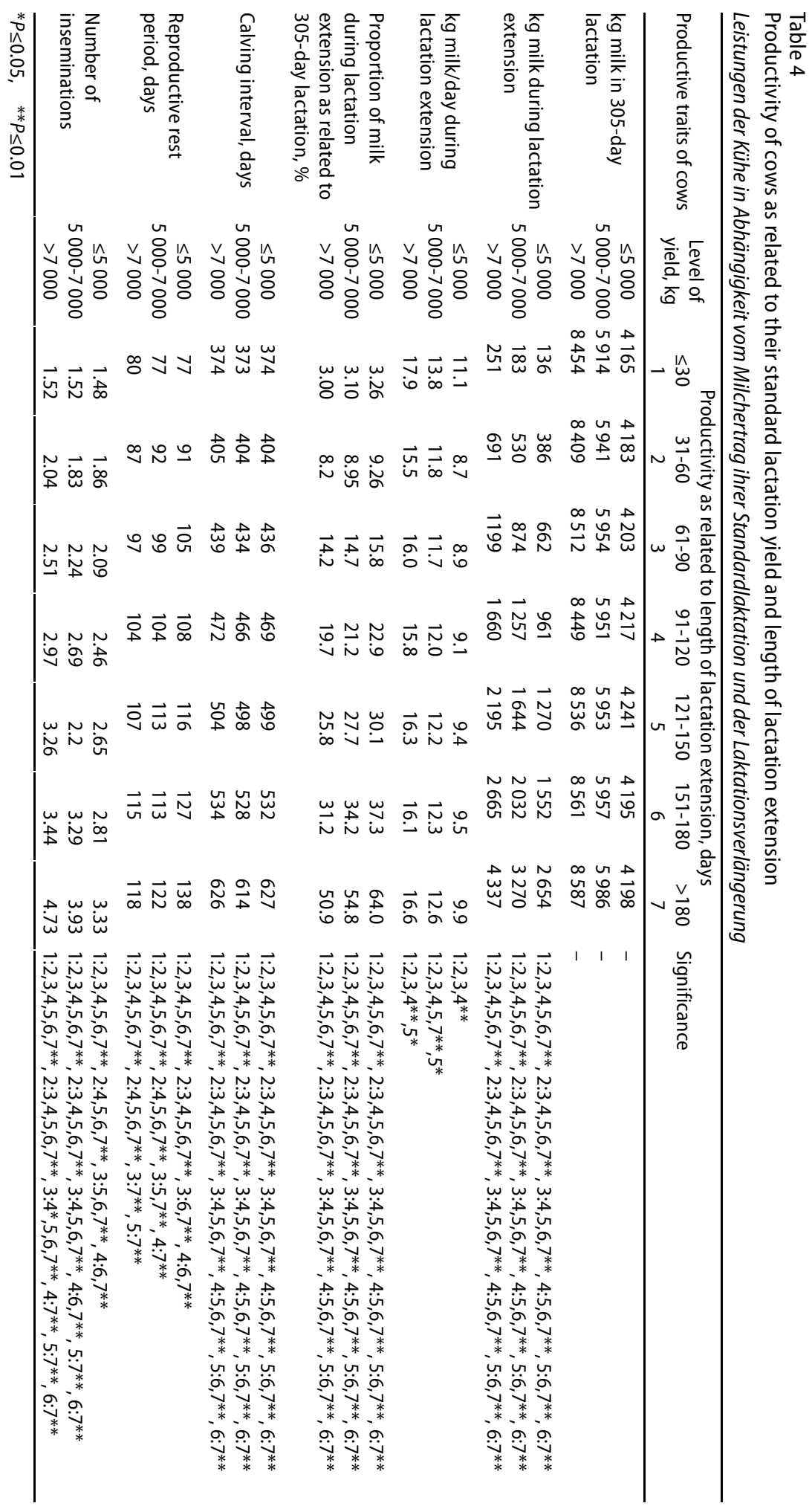




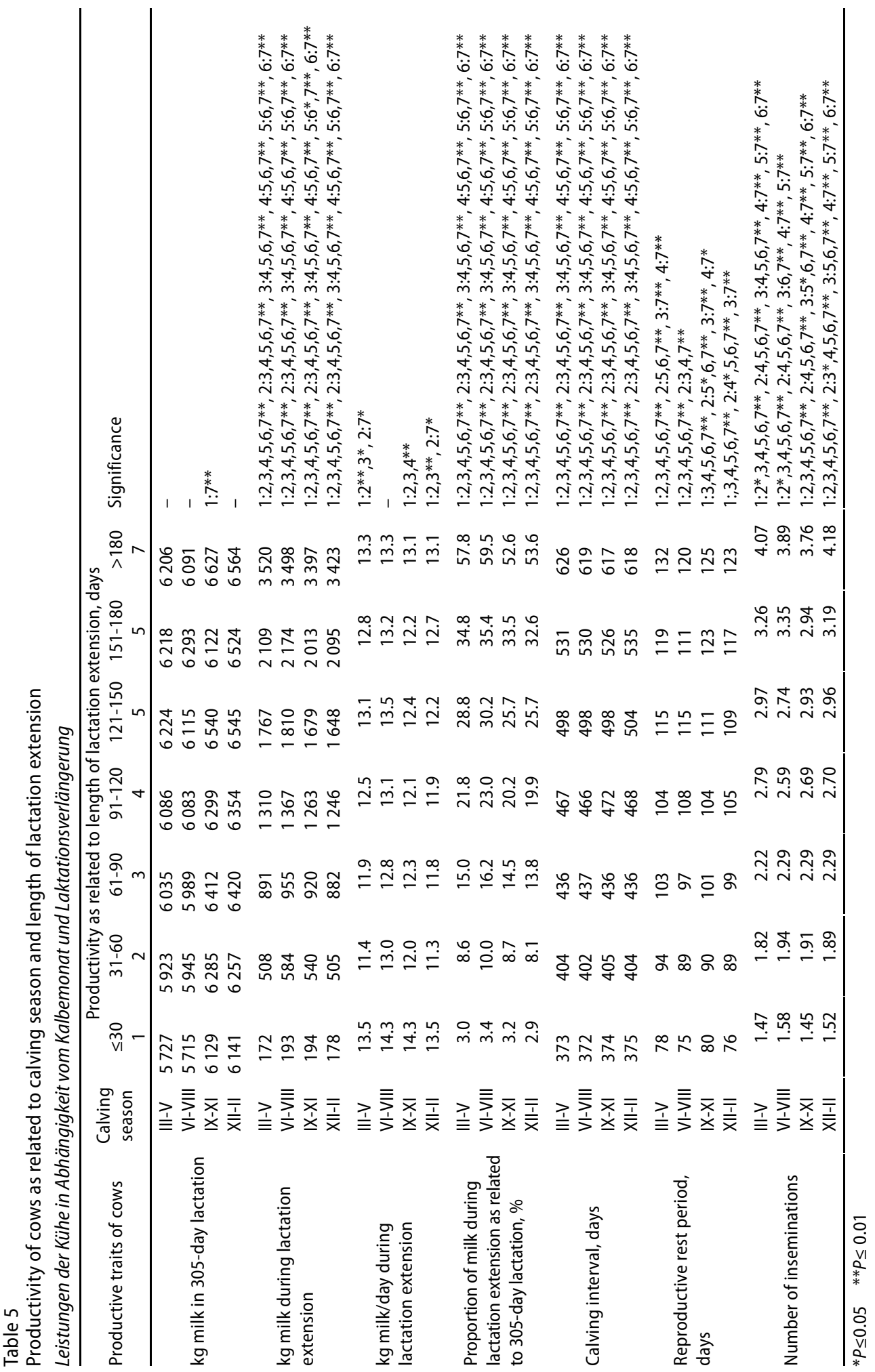


and standard lactation level of $>7000 \mathrm{~kg}$. During the extension period (regardless of its length), cows whose yield for a 305-day lactation exceeded $7000 \mathrm{~kg}$ milk produced almost twice as much milk as their contemporaries, whose level of yield per standard lactation did not exceed $5000 \mathrm{~kg}$. Cows which produced over $7000 \mathrm{~kg}$ milk in a standard lactation achieved the highest daily yield also during the extension period (by approx. $6.8 \mathrm{~kg}$ regardless of the extension length). The proportion of milk obtained during the extension ranged from approx. $3 \%$ when lactation was extended by up to 30 days to $51-60 \%$ when lactation was extended beyond 180 days, with higher values obtained for cows with a low level of yield in a standard lactation. Analysis of reproductive parameters showed that they were differentiated less by the level of yield in a standard lactation than by lactation extension. The results obtained demonstrate that the efficiency of lactation extension increases with the increasing level of yield in a standard lactation.

Of the factors analysed, calving season had the smallest effect on the differences in cow performance. Cows whose standard lactation yield was higher milked longer during full lactation, and it was shown that the 305-day lactation yield of autumn- and wintercalved cows was higher that that of spring- and summer-calved cows (differences up to $431 \mathrm{~kg}$ ) (Table 5). During lactations extended up to 90 days slightly more milk was obtained from summer- and autumn-calved cows, and during lactations extended beyond 90 days more milk was obtained from spring- and summer-calved cows. The highest daily yield during the extended lactation period was achieved by spring-calved cows but their superiority over winter-calved contemporaries did not exceed $1.7 \mathrm{~kg}$ milk/day. Cow fertility deteriorated with lactation extension, and the fertility parameters did not vary within calving seasons.

The positive coefficients of correlation (Table 6) between lactation extension length and milk yield during the extension period $\left(r=0.906^{* *}\right)$ and between lactation extension length and proportion of milk during the extension period in relation to a standard 305day lactation $\left(r=0.937^{* *}\right)$ fully confirm the results presented in Tables 3, 4 and 5 that cow yields increased steadily as lactations became longer. Analysis of the effect of lactation extension length on daily milk yield during the extension period showed a slight relationship between these traits. The correlation coefficients between lactation extension length and cow fertility were positive and statistically significant.

Table 6

Coefficients of correlation between length of lactation extension and productive traits

Korelationskoeffizienten zwischen Laktationsdauer und Leistungsmerkmalen

\begin{tabular}{lc}
\hline Trait & Coefficients of correlation \\
\hline Milk yield during full lactation, $\mathrm{kg}$ & $0.496^{* *}$ \\
Milk yield during 305-day lactation, kg & $0.070^{* *}$ \\
Milk yield during extension period, $\mathrm{kg}$ & $0.906^{* *}$ \\
kg milk/day during lactation extension & $-0.021^{* *}$ \\
Proportion of milk during lactation extension as related to 305-day lactation, $\%$ & $0.937^{* *}$ \\
Calving interval, days & $0.917^{* *}$ \\
Reproductive rest period, days & $0.330^{* *}$ \\
Number of inseminations & $0.536^{* *}$ \\
\hline
\end{tabular}

**P $P 0.01$ 


\section{Discussion}

The previous strategy for management of dairy herds was to obtain one calf per year as it was believed that the quicker the cow would be mated after calving, the more profitable it would be to produce milk (KRZYŻEWSKI and REKLEWSKI 2003). For this reason, a 305day lactation was considered optimal (BORKOWSKA 2005). The present findings show that $39 \%$ of lactations were longer than standard 305 days. Studies by SALAMOŃCZYK and GULIŃSKI (2007) in the Sokołów region demonstrated that $55 \%$ of lactations exceeded 305 days. CZAPLICKA et al. (2003) reported extended lactations in approx. $70 \%$ of cows (slightly more in Black-and-White than Holstein-Friesian cows). GULIŃSKI et al. (2004) reported that 531 out of 693 cows (76\% of all animals) extended their lactations. According to KHAN et al. (2007) 40,2\% cows had longer lactation than 308 days of duration.

Cow's age (lactation number) was shown to differentiate the proportion of extended lactations the most (Table 2). With each successive calving, the proportion of lactations extended up to 60 days increased and the proportion of lactations extended beyond 90 days decreased. Especially large differences (approx. 10\%) concerned the lactations extended up to 30 days and beyond 180 days. Longer lactations in first calvers compared to primiparas were reported by DYMNICKI et al. (2003), GULIŃSKI et al. (2004) and KRZYŻEWSKI et al. (2004). Studies by CZAPLICKA et al. (2003) and PIECH and TARKOWSKI (2001) showed that lactations became longer as cows became older. KRZYŻEWSKI and REKLEWSKI (2003) hold the view that lactation extension is particularly beneficial for first calvers, which are naturally characterized by greater lactation persistency. This enables young animals to reach full maturity at an earlier date and appropriate body condition before calving. SZAREK (1998) attributes the greater lactation persistency of first calvers compared to multiparas to the fact that first calvers grow intensively during the first lactation, as do their mammary glands.

Compared to primiparas, first calvers achieved lower yield per 305-day lactation and had lower daily yield during extended lactation (especially during the third lactation), but the proportion of milk during the lactation extension period in relation to a 305-day lactation was in their case the greatest regardless of extension period length. These results are in agreement with the findings of GULIŃSKI et al. (2004) and SALAMOŃCZYK and GULIŃSKI (2007).

Extended lactation is most often associated with extended CI (SZAREK 1998). Likewise, the present study showed that as lactation became longer, fertility deteriorated, especially in first calvers (Table 3).

According to KRZYŻEWSKI and REKLEWSKI (2003), the idea to retain standard 305-day lactations and year-long calving intervals is right only when the level of production is not very high. This is confirmed by our findings, which indicate that milk yield during extended lactation increased with lactation length and level of yield obtained by cows in a standard lactation, but the yield of cows that produced over $7000 \mathrm{~kg}$ milk in a standard lactation was, regardless of the extension period, almost twice that of cows which did not exceed $5000 \mathrm{~kg}$ in a standard lactation. It is also worth noting the high daily yield of highyielding cows, which exceeded $16 \mathrm{~kg} /$ day even during lactations extended beyond 180 days. Likewise, CZAPLICKA et al. (2003) reported that extended lactations in heavy 
milking cows did not reduce the yield per day of lactation. HIBNER et al. (1999) also found persistently high daily yield of cows during the final period of extended lactation. This phenomenon is believed to be characteristic of Holstein-Friesian cows or crossbreds with high $\mathrm{HF}$ inheritance, kept under very good production conditions.

The increase in the amount of milk obtained during extended lactation, found in the present study together with the increased level of yield is consistent with the findings of GULIŃSKI et al. (2004) and SALAMOŃCZYK and GULIŃSKI (2007). However, the percentage of milk produced during extended lactation in relation to the amount of milk obtained in a 305-day lactation decreased with the increased level of yield in a standard lactation. This tendency was also prevalent in other studies (GULIŃSKI et al. 2004, SALAMOŃCZYK and GULIŃSKI 2007).

Analysis of the relationships between the utilization of cows for milk and reproduction gains special importance because the current strategy for cattle husbandry development foresees that milk yield should be increased on a regular basis. SZAREK (1998) and GULINSSI et al. (2004) as well as the authors they quote believe that lactation length is largely dependent on $\mathrm{Cl}$ length. This thesis is fully confirmed by the results of the present study, in which the correlation between lactation extension length and $\mathrm{Cl}$ length was $0.917^{* *}$ (Table 6). The results obtained for the effect of extended lactations on fertility are in agreement with the results of other authors, who showed that the slightly less beneficial reproductive parameters of the cows in groups with extended $\mathrm{Cl}$ and longer lactations are compensated by higher milk yield (KRZYŻEWSKI et al. 2004, STRZAŁKOWSKA et al. 2004).

The average number of inseminations per pregnancy increased with the increasing level of standard lactation, especially with lactation extension. For cows producing up to $5000 \mathrm{~kg}$ milk per standard lactation, the insemination index increased with extended lactation from 1.48 to 3.33 , and for high-yielding cows (over $7000 \mathrm{~kg}$ milk per 305-day lactation) the insemination index increased with extended lactation from 1.52 to as much as 4.73. This shows, among others, that despite external signs of oestrus, the cowss body was not ready for fetal implantation in the reproductive tract. According to SWANSON (1989), mammary gland function has priority over the reproductive system in highyielding cows.

One of the factors that affect the milk yield of cows is calving season. Analysis of the means characterizing the effect of calving season on milk yield in a standard lactation showed that it was approx. $400 \mathrm{~kg}$ higher in the autumn-winter season than in the spring-summer season. This difference was much lower than for the effect of the other factors. Also other productive traits were much less differentiated by the effect of calving season than by the effect of lactation number or level of yield in a standard lactation.

\section{References}

Bielfeld JCh , Badertscher R, Tölle K, Krieter J (2004) Influence of systematic effects on fertility traits in Swiss Brown cows. Arch Tierz 47, 537-49

Bertilsson J, Berglund B, Osterman S, Rehn H, Tengroth G (1998) Extended calving intervals - a way to optimist future milk production? Effects on productivity Book of Abstracts of the $49^{\text {th }}$ Annual Meeting of the EAAP Warsaw 24-27 August 1998 
Borkowska D (2005) Diary use, in cattle breeding and use ed. Litwińczuk Z Szulc T PWRiL Warszawa 2005 ss 414 [in Polish]

Czaplicka M, Puchajda Z, Szalunas T (2003) Comparison of the lenght of lactation the inter-calving period and milk yield during four lactations of cows imported from France and domestic Black-andWhite ones. Zesz Nauk Prz Hod 68, 107-14 [in Polish]

Dymnicki E, Krzyżewski J, Oprządek J, Reklewski Z, Oprządek A (2003) Relationship between the length of calving intervals and milk trace in black-and-white cows. Med Wet 59, 792-6 [in Polish]

Gulińki P, Młynek K, Dobrogowska E (2004) The importance of extender lactation for Black-and-White cows milk yield. Zesz Nauk Prz Hod 72, 67-74 [in Polish]

Hibner A, Zachwieja A, Juszczak J, Ziemiński R (1999) Length of inter calving period and effectiveness of milk production in high milk yielding herds. Med Wet 55, 753-6 [in Polish]

Hinrichs D, Stamer E, Junge, Kalm E (2006) Genetic analysis of several disease categories using test day threshold models in German Holstein cows. Arch Tierz 49, 3-16

Khan MS, Hassan FU, Rehman MSU, Hyder AU, Bajwqa IR (2007) Genetic control of milk yield from lactations of different duration in Nili-Ravi buffaloes. Arch Tierz 50, 227-39

Knight CH, Orensen A, Muir DD (1998) Biological control of lactation persistency and milk quality Book of Abstracts of the 49th Annual Meeting of the EAAP Warsaw 24-27 August 1998

Krzyżewski J, Reklewski Z (2003) Influence of extender calving intervals on milk field chemical composition technological parameters and reproductive performance of cows. Zesz Nauk Prz Hod 67, 7-17

Krzyżewski J, Strzałkowska N, Reklewski Z, Dymnicki E, Ryniewicz Z (2004) Influence of calving interval length in HF cows on milk yield its composition and some reproduction traits. Med Wet 60, 76-9 [in Polish]

Piech M, Tarkowski J (2001) Length of Calving Intervals in the Black and White Cows Herd and Their Relation to Milk Yield. Annales UMCS Lublin Polonia vol XIX 3 EE 2001, 17-26 [in Polish]

Salamończyk E, Guliński P (2007) Influence of selected genetic and environmental factors on lactation extension in cows and milk yield during extended lactation. II. Milk yield during complete lactations longer than 305-day lactation. Rocz Nauk Zoot 34, 55-65 [in Polish]

SAS (2004) SAS/STAT 9.1 User's Guide. Cary NC SAS Institute Inc

Sawa A, Jankowska M, Neja W, Bogucki W, Oler A (2002) High productivity and course of lactation curve and fertility and cow culling. Zesz Nauk Prz Hod 62, 145-53 [in Polish]

Seeland G, Henze C (2003) Relations between milk yield and fertility after strong increased milk yield. Arch Tierz 46, 103-12 [in German]

Sölkner J, Miesenberger J, Willam A, Fuerst C, Baumung R (2000) Total merit indices in dual purpose cattle. Arch Tierz 43, 597-608

Strzałkowska N, Krzyżewski J, Reklewski Z, Dymnicki E (2004) Relationship between the strained length of calving intervals some reproduction traits and adjusted cow's milk yield. Med Wet 60, 1312-6 [in Polish]

Swanson LV (1989) Interaction of nutrition and reproduction. J Dairy Sci 72, 805-14

Szarek J (1998) Cattle production commission. Zesz Nauk Prz Hod 38, 45-55 [in Polish]

Received 10 September 2008, accepted 8 December 2008.

Corresponding author:

Prof.Dr. hab. ANNA SAWA

email: sawa@utp.edu.pl

Department of Cattle Breeding, Faculty of Animal Breeding and Biology, University of Technology and Life Sciences in Bydgoszcz, Mazowiecka 28, 85-084 Bydgoszcz, Poland 